\title{
Cytotoxic effects of cladribine and tezacitabine toward HL-60
}

\author{
Krzysztof Stachnik ${ }^{1}$, Paweł Grieb ${ }^{2}$ and Janusz S. Skierski ${ }^{1 凶}$ \\ ${ }^{1}$ Flow Cytometry Laboratory, National Institute of Public Health, Warszawa, Poland, ${ }^{2}$ Department of Experi- \\ mental Pharmacology, Mossakowski Medical Research Center, Polish Academy of Sciences, Warszawa, Poland, \\ 区e-mail: skierski@il.waw.pl
}

Received: 26 July, 2004; revised: 25 January, 2005; accepted: 10 February, 2005

available on-line: 31 May, 2005

\begin{abstract}
The aim of the study was to determine the relation between the cytotoxic and cytostatic effects of tezacitabine and cladribine on a HL-60 cell line and the time of exposure of cells to these drugs. Cell viability and induction of apoptosis were assessed using flow cytometry methods. Apoptosis was confirmed by direct microscopic observation. Growth inhibition was examined by cell counting. After $24 \mathrm{~h}$ incubation tezacitabine was equally or less toxic compared to cladribine. However, toxicity of tezacitabine strongly rose after $48 \mathrm{~h}$ incubation leading to massive cell death at doses much lower than those of cladribine. Assessment of the effect of increased exposure time on the clinical efficacy of tezacitabine is indicated.
\end{abstract}

Keywords: cladribine, tezacitabine, leukemia, HL-60 cells, nucleoside analogs, flow cytometry

Several cytotoxic purine and pyrimidine nucleosides have proved useful for chemotherapy of various hematological and epithelial malignacies (Galmarini et al., 2001; Faderl et al., 2002). Development of these drugs has usually been empirical. In vitro assays of cytotoxicity toward a panel of established malignant cell lines and phase I clinical studies have been employed to select tumor types susceptible to a drug and to determine its maximal tolerated dose (MTD), respectively. The aforementioned types of studies are rarely sufficient to establish an optimal dosing schedule, which later undergoes modifications according to the results of pharmacokinetic studies and clinical evaluations of safety and efficacy.

The development of the purine analog cladribine (2-chloro-2'-deoxyadenosine, 2CdA) may serve as an example of such modifications of dosing schedule. The drug is particularly effective in HCL where more than $90 \%$ of complete remissions have been reported repeatedly (Piro et al., 1990; Robak et al., 1999). It also displays a considerable clinical activity in some other lympho- and myeloproliferative diseases including B-CLL (Karlsson et al., 2002), low-grade non-Hodgkin's lymphoma (Robak et al.,
1997) and chronic myelogenous leukemia (Gollard et al., 1997). The MTD of cladribine in patients with leukemias and lymphomas has been established as $0.7 \mathrm{mg} / \mathrm{kg}$ per treatment course, courses repeated at monthly intervals (Saven \& Piro, 1994). In the first clinical trial cladribine was given as 7-day long continuous infusion because it was thought that a week-long exposure of malignant lymphocytes to the drug was a prerequisite of optimal cytotoxic effect (Piro et al., 1990). However, pharmacokinetic studies provided evidence that the drug enters lymphocytes within 1-2 $\mathrm{h}$ and accumulates intracellularly in the form of relatively stable phosphates (Liliemark, 1997). Treatment courses consisting of 5 daily doses given either as 2 hour-long i.v. or s.c. infusions $(0.14 \mathrm{mg} / \mathrm{kg}$ per day), or orally $(0.28 \mathrm{mg} /$ $\mathrm{kg}$ per day) were found to be similarly effective as 7 day-long continuous infusions (Liliemark \& Juliusson, 1995). Subsequent trials have shown that courses consisting of three daily doses of cladribine repeated every third week for up to 10 courses in B-CLL (Karlsson et al., 2002) and doses $0.15 \mathrm{mg} / \mathrm{kg}$ given at weekly intervals in HCL (Lauria et al., 1999) are similarly effective and accompanied by less severe side effects. Furthermore, when cladribine was

Abbreviations: B-CELL, B-cell chronic lymphocytic leukemia; 2CdA, cladribine, 2-chloro-2'-deoxyadenosine; dCK, deoxycytidine kinase; DAPI, 4',6-diamidino-2-phenylindole; FDA, fluorescein diacetate; FMdC, tezacitabine, $((E)$-2'-deoxy2'-(fluoromethylene)-cytidine; HCL, hairy cell leukemia; i.v., intravenous; PBS, phosphate buffered saline; PI, propidium iodine; s.c., subcutaneous. 
used as an immunosuppressant to treat multiple sclerosis, the same cumulative dose was markedly more effective in reducing the number of circulating lymphocytes when given once a week than when given in courses consisting of five consecutive daily doses and repeated monthly (Grieb et al., 2001). It has been suggested that when the injections are repeated daily, the entry of cladribine to the lymphocytes may be blocked by deoxycytidine which is liberated from dying cells and competes with the drug for its phosphorylating enzyme, deoxycytidine kinase (dCK) (the evidence for such competition has been found in vitro (Cohen et al., 1997)).

Tezacitabine ((E)-2'-deoxy-2'-(fluoromethylene)cytidine, FMdC) is a novel pirimidine derivative undergoing clinical development as a treatment for both hematological malignancies (Faderl et al., 2002) and solid tumors (Seley, 2000). Its MTD has been established at $7.5 \mathrm{mg} / \mathrm{m}^{2} /$ day for 5 days (Faderl et al., 2001). Various dosing schedules were employed in the studies reported to date. Patients with solid tumors were treated with 30-minute-long i.v. infusions repeated either every three weeks, or twice a week for three weeks (Rodriguez et al., 2002; Flaherty et al., 2003). In a preliminary study with hematological malignancies the drug was also given as 30-min i.v. infusions, and the doses were repeated daily for 5 consecutive days (Faderl et al., 2001). In an on-going study tezacitabine is given as continuous i.v. infusion (Faderl et al., 2002). The question which type of dosing schedule (short or longer exposure of malignant cells to the drug) will yield optimal cytotoxic effect remains open.

To find out whether a prolonged exposure of leukemic cells to tezacitabine will increase the cytotoxicity of the drug, in the present study we compared the effects of continuous exposure of HL-60 leukemia cells to various concentrations of FMdC and 2CdA for 24 and $48 \mathrm{~h}$.

\section{MATERIALS AND METHODS}

Chemicals. FMdC was synthesized by Drs. M. Bretner and K. Felczak (Institute of Biochemistry and Biophysics, Polish Academy of Sciences, Warszawa, Poland) according to the modified method of McCarthy et al. (1991). Its chemical identity and purity was confirmed by proton NMR and HPLC, respectively. 2CdA (pharmaceutical grade, >99\% by HPLC) was a gift from the Foundation for Development of Diagnostics and Therapy (Warszawa, Poland). Both substances were prepared as $1 \mathrm{mM}$ stock solution in PBS (Institute of Immunology and Experimental Therapy, Poland). Annexin V kit from Caltag (USA), fluorescein diacetate (FDA) from Sigma (USA), 4',6-diamidino-2-phenylindole (DAPI), sulforhodamine 101 and propidium iodide (PI) from
Molecular Probes (USA), and Isoton II from Beckman Coulter (USA) were used.

Cell culture and drug exposure. HL-60 human promyelocytic leukemia cells (ATCC, USA) were cultured in RPMI 1640 medium (Institute of Immunology and Experimental Therapy, Poland) supplemented with $20 \%$ fetal bovine serum, L-glutamine and antibiotic-antimycotic solution (Gibco, USA) in a humidified $5 \% \mathrm{CO}_{2} / 95 \%$ air atmosphere at $37^{\circ} \mathrm{C}$. Cell cultures were routinely checked for mycoplasma contamination. For experiments $3 \times 10^{5}$ cells $/ \mathrm{ml}$ in $2 \mathrm{ml}$ medium were seeded in a 12-well plate (Nunc, Denmark). HL-60 cells were exposed continuously to the same concentrations of $2 \mathrm{CdA}$ or FMdC, namely $10,25,50,100$ or $200 \mathrm{nM}$ in final volume of the medium, for either 24 or 48 h. Cells were subsequently collected, spinned down, rinsed with cold PBS and prepared for labeling.

Flow cytometry. Cytometric data were collected using a FACSVantage flow cytometer and analyzed by CellQuest software (BD Biosciences, USA).

Apoptosis assay by Annexin V/PI labeling. After washing with PBS $10^{6}$ cells per ml were suspended in binding buffer on ice. Aliquots of $100 \mu \mathrm{l}$ of the cell suspension were labeled using AnnexinV kit, according to manufacturer's procedure. Briefly, $5 \mu \mathrm{l}$ of Annexin V-FITC and $10 \mu \mathrm{l}$ of $50 \mu \mathrm{g} / \mathrm{ml}$ PI were added and incubated for $15 \mathrm{~min}$ at room temperature in the dark, then $400 \mu \mathrm{l}$ of cold binding buffer was added and cells were mildly vortexed and kept on ice. Flow cytometry measurements were performed $1 \mathrm{~h}$ after labeling.

Viability assay by FDA/PI labeling. After washing with PBS $10^{6}$ cells per $\mathrm{ml}$ were suspended in cold PBS and $100 \mu \mathrm{l}$ aliquots of the cell suspension were labeled with a slightly modified method of Ross et al. (1989). Briefly, $10 \mu \mathrm{l}$ of $0.5 \mu \mathrm{g} / \mathrm{ml}$ FDA and $10 \mu \mathrm{l}$ of $50 \mu \mathrm{g} / \mathrm{ml}$ PI were added for $5 \mathrm{~min}$ at room temperature, then $400 \mu \mathrm{l}$ of cold PBS was added and cells were mildly vortexed and kept on ice. Flow cytometry measurements were performed within $1 \mathrm{~h}$ after labeling.

Growth inhibition. Cells were collected directly from the culture after exposure to the drugs, suspended in cold Isoton II buffer and counted in a Coulter Counter Z2 (Beckman Coulter, USA). Growth inhibition was calculated from the formula: $\left[\left(C_{k}-C_{p}\right) /\left(C_{K O N}-C_{p}\right)\right] \times 100 \%$, where $C_{p}-$ cell count at the beginning of the experiment; $C_{k}-$ cell count after incubation with medium containing the tested drug; $\mathrm{C}_{\mathrm{KON}}$ - cell count after incubation with medium containing no drug (Monks et al., 1991).

Morphological evaluation. Cells were collected after exposure to the drugs, washed in cold PBS and fixed in ice cold $70 \%$ ethanol for at least $24 \mathrm{~h}$, then washed out from alcohol and stained with 1.0 $\mu \mathrm{g} / \mathrm{ml}$ DAPI and $10 \mu \mathrm{g} / \mathrm{ml}$ sulforhodamine 101 for 1 h. Cell morphology was evaluated using BX60 fluo- 
rescence microscope equipped with digital camera DP50 (Olympus, Japan), under Nomarsky contrast and fluorescence.

Statistics. All experiments were repeated at least 4 times. The results are presented as arithmetic means \pm standard deviations. Statistical analysis was performed using the Statistica for Windows software (StatSoft, USA), version 6.0. Three-way ANOVA was used to compare data from $2 \mathrm{CdA}$ and FMdC treatments. To assess the significance of differences between the untreated group and each of the actively treated groups, Tukey post-hoc test was used, $P$ values less than 0.05 (marked with asterisks on graphs) were considered as statistically significant.

\section{RESULTS}

The effects of drug treatment at variant concentrations and exposure times on cell viability, induction of apoptosis and growth inhibition were highly significant $\left(P<10^{-6}\right)$. The interactions between these three independent variables according


Figure 1. Decrease in viability of HL-60 cells after 2CdA or FMdC treatment.

Cells were incubated for: A) $24 \mathrm{~h}$ or B) $48 \mathrm{~h}$, respectively, with various concentrations of FMdC (empty bars) or 2CdA (dashed bars). Cells were washed and stained with FDA/PI. Viability was assessed by flow cytometry. Asterix denotes results statistically significant at $P<0.05$. to the viability and apoptosis results were also highly significant $\left(P<10^{-6}\right)$.

A dose- and time-dependent decrease of cell viability was observed during incubation with both substances. However, at $24 \mathrm{~h} 2 \mathrm{CdA}$ at the highest dose (200 nM) was significantly more cytotoxic (Fig. 1a), whereas at $48 \mathrm{~h}$ it was significantly less cytotoxic than FMdC (Fig. 1b).

Both drugs induced dose- and time-dependent cell apoptosis as detected by phosphatidylserine translocation. After $24 \mathrm{~h}$ exposure their effects were of comparable magnitude (Fig. 2a). However, after $48 \mathrm{~h}$ of exposure the proapoptotic effects of FMdC were significantly stronger, except for the higher concentrations (100 and $200 \mathrm{nM}$ ) at which virtually all cells were in apoptosis (Fig. 2b).

Both substances appeared to be efficient in growth inhibition at both exposure times, but FMdC suppressed the growth of cells at significantly lower doses than $2 \mathrm{CdA}\left(\mathrm{GI}_{50}\right.$ for FMdC at $24 \mathrm{~h}$ and $48 \mathrm{~h}$ $<25 \mathrm{nM}$ and $<10 \mathrm{nM}$, respectively, compared to $>50 \mathrm{nM}$ and > $25 \mathrm{nM}$ for 2CdA (Fig. 3). No differences were observed at the highest doses, at both


Figure 2. Induction of apoptosis of HL-60 cells after $2 \mathrm{CdA}$ or FMdC treatment.

Various concentrations of FMdC (empty bars) or 2CdA (dashed bars), were added to cultured cell for: A) $24 \mathrm{~h}$ or B) $48 \mathrm{~h}$ incubation, respectively. Treated cells were washed and stained with Annexin V/PI. Apoptosis occurrence was tested by flow cytometry. Asterix denotes results statistically significant at $P<0.05$. 
A



B



Figure 3. Growth inhibition of HL-60 cells after drug treatment.

Cells were incubated for: A) $24 \mathrm{~h}$ or B) $48 \mathrm{~h}$, respectively, with various concentrations of FMdC (empty bars) or 2CdA (dashed bars). Cells were counted using Coulter Counter. Asterix denotes results statistically significant at $P<0.05$.

exposure times the growth inhibition was very efficient.

The apoptotic death of cells was confirmed by morphological examination (Fig. 4). The shrinkage of cells, chromatin condensation and formation of apoptotic bodies were found at higher concentrations and longer exposure times.
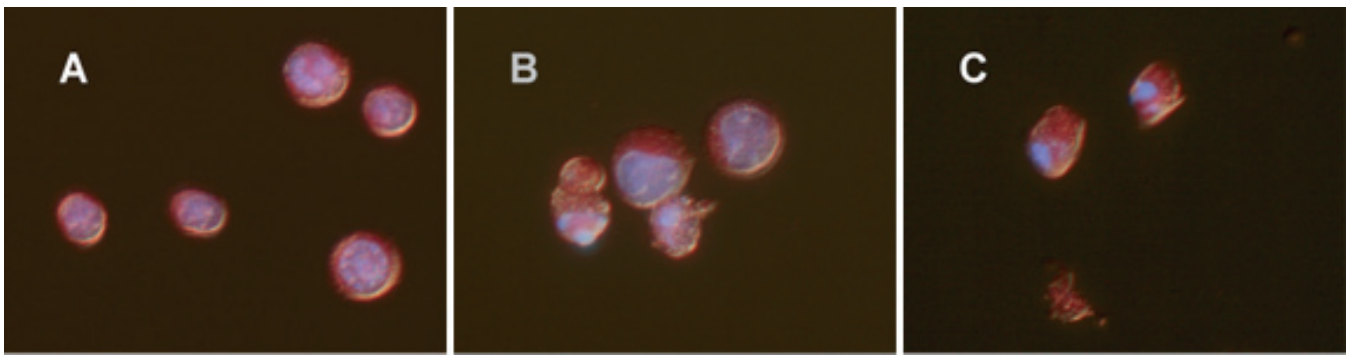

Figure 4. Morphological examination of cells stained with DAPI/sulforhodamine 101.

HL-60 cells were incubated for $48 \mathrm{~h}$ with 2CdA or FMdC, respectively. Morphology of cells was observed using fluorescence microscope. No changes were observed for untreated cells (A). Typical changes, like chromatin condensation and formation of apoptotic bodies were observed for cells treated with $50 \mathrm{nM} 2 \mathrm{CdA}(\mathrm{B})$ and cells treated with $100 \mathrm{nM}$ FMdC (C). 
sponse develops much more slowly in the case of FMdC.

Whatever the mechanism responsible for the relatively slow development of cytotoxic effects of tezacitabine toward HL-60 leukemia cells, there is an obvious need to study the intracellular pharmacokinetics of this drug in different types of target tissues, i.e., in solid tumors as well as in leukemias. Until such data become available, continuous infusion of tezacitabine over at least two days may be a rational approach in clinical efficacy studies of this drug in hematological malignancies.

\section{Acknowledgements}

Tezacitabine synthesis was supported in part by the Foundation for the Development of Diagnostics and Therapy, Warszawa, Poland.

\section{REFERENCES}

Cohen JD, Strock DJ, Teik JE, Katz TB, Marcel PD (1997) Cancer Lett 116: 1671-1675.

Faderl S, Garcia-Manero G, Thomas DA, Cortes J, O'Brien S, Giles FJ, Koller CA, Beran M, Verstovsek S, Kwari M, Ghandi V, Plunkett W, Kantarjian HM (2001) Blood 98: 2493.

Faderl S, Gandhi V, Kantarjian H, Plunkett W (2002) In Cancer Chemot Biol Resp Mod. Ann 20. Giaccone G, Schilsky R, Sondel P, eds, pp 37-58. Elsevier Science B.V.

Flaherty KT, Stevenson JP, Gallagher M, Giantonio B, Algazy KM, Sun W, Haller DG, O'Dwyer PJ (2003) Cancer 97: 1985-1990.

Galmarini CM, Mackey JR, Dumontet C (2001) Leukemia 15: $875-890$.

Grieb P, Koronkiewicz M, Skierski JS (2000) Acta Biochim Polon 47: 165-171.

Grieb P, Kamienowski J, Janisz M, Kusnierczyk P, Kawiak J, Hoser G, Chrapusta SJ (2001) Int J Hematol 74: 421-427 .
Gollard R, Miller WE, Piro LD, Saven A (1997) Leuk Lymphoma 28: 183-185.

Griffig J, Koob R, Blakley RL (1989) Cancer Res 49: 69236928.

Karlsson K, Stromberg M, Liliemark J, Delannoy A, Johnson SA, Porwit A, Kimby E, Larfars G, Cristiansen I, Nilsson G, et al. (2002) Br J Haematol 116: 538-548.

Lauria F, Bocchia M, Marotta G, Raspadori D, Zinzani PL, Rondelli D (1999) Haematologica 84: 22-25.

Liliemark J (1997) Clin Pharmacokinet 32: 120-131.

Liliemark J, Juliusson G (1995) Clin Cancer Res 1: 385-390.

McCarthy JR, Matthews DP, Stemerick DM, Huber EW, Bey P, Lippert BJ, Snyder RD, Sunkara P (1991) J Am Chem Soc 113: 7439-7440.

Monks A, Scudiero D, Skehan P, Shoemaker R, Paull K, Vistica D, Hose C, Langley J, Cronise P, Vaigro-Wolff A, et al. (1991) J Natl Cancer Inst 83: 757-766.

Piro LD, Carrera CJ, Carson DA, Beutler E (1990) N Engl J Med 322: 1117-1121.

Robak T, Gora-Tybor J, Krykowski E, Walewski JA, Borawska A, Pluzanska A, Potemski P, Hellmann A, Zaucha JM, Konopka L, et al. (1997) Leuk Lymphoma 26: 99-105.

Robak T, Blasinska-Morawiec M, Blonski J, Hellmann A, Halaburda K, Konopka L, Kotlarek-Haus S, Potoczek S, Hansz J, Dmoszynska A, et al. (1999) Eur J Haematol 62: 49-56.

Rodriguez GI, Jones RE, Orenberg EK, Stoltz ML, Brooks DJ (2002) Clin Cancer Res 8: 2828-2834.

Ross DD, Joneckis CC, Ordonez JV, Sisk AM, Wu RK, Hamburger AW, Nora RE (1989) Cancer Res 49: 37763782.

Saven A, Piro LD (1994) Ann Intern Med 120: 784-791.

Seley KL (2000) Curr Opin Investig Drugs 1: 135-140.

Skierski JS, Koronkiewicz M, Grieb P (1999) Cytometry 37: 302-307.

Takahashi T, Nakashima A, Kanazawa J, Yamaguchi K, Akinaga S, Tamaoki T, Okabe M (1998) Cancer Chemother Pharmacol 41: 268-274. 